\title{
EFFECTS OF STORAGE CONDITIONS ON QUALITY CHARACTERISTICS OF COMMERCIAL AQUAFEEDS AND GROWTH OF AFRICAN CATFISH Clarias gariepinus
}

\section{Shola Gabriel Solomon, Lateef Oloyede Tiamiyu, Victor Tosin Okomoda*, Kamwan Adaga}

Department of Fisheries and Aquaculture, University of Agriculture, Makurdi, Nigeria

*Corresponding author, Email: okomodavictor@yahoo.com

\section{ARTICLE INFO}

Received: 14 December 2015

Received in revised form: 24 February 2016

Accepted: 9 March 2016

Available online: 10 March 2016

\section{ABSTRACT}

This study was conducted to determine the effect of storage conditions on the quality of feed and the aftermath effect of feeding fish with such feeds. Three commercial diets used for this study included Coppens, Multifeed ${ }^{\circ}$ and Vital feed ${ }^{\circ}$. Feed was stored either by opening the bag to the atmosphere (WO), the bag opened with neck tied using a rubber ring to prevent exposure to the atmosphere (OT) or sealed (SC) until the start of the feeding trials. The feed was stored under these conditions for six months. Nutrient analyses revealed significant changes in feeds held under the WO condition when compared with other storage conditions. Nutritive changes also varied with commercial feed type. Mould infestation of the feed was noticeable more in the WO condition of storage compared to the SC condition. After feeding C. gariepinus for fifty-six days, lesions were observed on fish fed mouldy feed held under the WO condition, which led to mass mortalities. Growth performance was higher in all fish fed SC stored feed, and for those fed Coppens ${ }^{\circ}$ and Multifeed ${ }^{\circ}$ under OT storage conditions. It is advised that storage of fish feeds up to six months should be undertaken with considerable care and attention.

Solomon S.G., Tiamiyu L.O., Okomoda V.T., Adaga K. (2016): Effects of storage conditions on quality characteristics of commercial aquafeeds and growth of African catfish Clarias gariepinus. Journal of Fisheries, 74, 3037. DOI: $10.1515 /$ cjf-2016-0006

\section{INTRODUCTION}

To sustain fish under culture, supplementation diet must be provided to complement natural feeds supply (Karapan, 2002). Generally, nutrition of fish is an important aspect of any viable aquaculture enterprise accounting for at least $60 \%$ of the total cost of fish production (Jamu and Ayinla, 2003; Madu et al., 2003). The nutrient composition of feed influences feed utilization and ultimately the growth of fish (Adaga, 2014).

The prevailing climatic conditions in the tropics experience an increase in temperature and relative humidity of over $25^{\circ} \mathrm{C}$ and $70 \%$, respectively (Adaga, 2014). Such conditions accelerate mould growth and lipid oxidation (Berger,
1989; Coppen, 1989; Van den Bergh, 1990). According to Bautista et al. (1992) and Ramezandeh et al. (1999), feed storage at high temperature results in an increase in both oxidative and hydrolytic rancidity with loss in feed quality. Studies by Van den Bergh et al. (1990) and Ruiz et al. (2000) indicate that fats are intrinsically unstable when subjected to high temperature above $30^{\circ} \mathrm{C}$. Under such conditions, fats are hydrolysed to release ketonic acids, which further undergo auto-oxidation with degeneration of free radical products (Hamilton, 1989). According to FAO (2001), these environmental factors also predispose fish feeds to microbial spoilage, hence causing feeds to decompose and fed fish to become diseased. Toxin producing fungi are dangerous, 
most of them producing aflatoxins, patulins and trichotecens which are strongly carcinogenic and mutagenic (Ciceron et al., 2008; Brown, 2001). Aflatoxins are chemicals produced by fungi such as Aspergilus flavus and $A$. parasiticus (mould) (Russo and Yanong, 2006). Mould infested fish feeds have been reported to impact negatively the growth of vundu Heterobranchus bidorsalis (Effiong and Alatise, 2009).

Manufactured feeds are stored under different storage conditions by commercial fish feed sellers and farmers without respect to the effect of these conditions on the nutrient profiles of the feeds (Adaga, 2014). Since the nutrient profile of a feed determines the growth performance of fish, this study was designed to investigate effect of storage conditions on feed nutrient quality and performance of African catfish Clarias gariepinus. African catfish was chosen for this study because of its availability, economic importance, fast growth rates, tolerance to crowded conditions, high feed conversion, high consumer acceptability, high quality of its flesh and high adaptation to poor environmental conditions (Olufeagaba, 1999; Ataguba et al., 2010; Solomon et al., 2013).

\section{MATERIALS AND METHODS}

The experiment was carried out in the postgraduate laboratory of the Department of Fisheries and Aquaculture, University of Agriculture, Makurdi. Twelve kilograms of each of Coppens ${ }^{\circ}$, Multifeed ${ }^{\circ}$ and Vital feed ${ }^{\circ}$ was purchased from a reputable feed store along a modern market road, Makurdi, Nigeria. For the purpose of this study, various experimental feeds were divided into three halves ( $4 \mathrm{~kg}$ ) and stored under different storage conditions for a period of six months. The first set of feeds was widely open to the atmosphere (WO), the second set had the bag opened and the open edge tied using a rubber ring to prevent exposure to the atmosphere (OT), while the last set which served as the control remained sealed until the start of the feeding trials (SC). Samples were collected at the end of six months for different nutrient analyses. Proximate analysis of feeds and fish carcass was determined using the methods of AOAC (2002). Parameters measured included moisture, ash, crude fibre, ether extract and crude protein, while nitrogen-free extract (NFE) was determined by difference.

Peroxide value (POV) and free fatty acid (FFA) analysis was also done according to AOAC (2002). Oils with POV well below $10 \mathrm{mg} / \mathrm{kg}$ were considered fresh, while oils with POV between 20-40 mg/kg were termed rancid. Mould growth was identified according to the method described by APHA (1998). Seven hundred and twenty fingerlings were obtained from the University research farm and acclimatized under laboratory conditions for two weeks prior to the start of the feeding trial (with 10\% mortality recorded during acclimation). Twenty fingerlings were randomly selected and stocked in triplicate plastic basins (50 L) and assigned to the different treatment according to the different commercial diet and the system of storage. The fingerlings were starved for a day ( $24 \mathrm{hrs}$ ) before commencement of feeding trials to allow the emptying of the gastro-intestinal tract in anticipation of the experimental diets. The fingerlings were hand-fed $5 \%$ of their body weight; this was divided and administered to the fish twice daily (8:00 am and 5:00 $\mathrm{pm}$ ). Bulk weights of the fish were taken weekly and feeding rate was adjusted accordingly. The experimental tanks were aerated throughout the experimental period to ensure oxygen availability. Uneaten feed and faecal droppings were removed by siphoning using capillary tubes of $0.8 \mathrm{~mm}$ lateral diameter after three hours of administering food. Water quality parameters such as temperature, dissolve oxygen (DO), $\mathrm{pH}$, conductivity and total dissolved solids were monitored to ensure that they were within recommended ranges throughout the experimental period (Temp, $32-35^{\circ} \mathrm{C}$; DO, 4-5 $\mathrm{mgl}^{-1} ; \mathrm{pH}, 6.5-7.0$; Conductivity, 114-150 umhos/ $\mathrm{cm}$; TDS, 50-95 $\mathrm{mgl}^{-1}$ ). When water quality parameters were getting too critical, complete tank water exchange was undertaken. After feeding the fish for eight weeks, growth performance and nutrient utilization were assessed using the relations below:

a) Mean Initial Weight (MIW) TotlitialWeightofFingerlings TotalNumberofFingerlings

(b) Mean Weight Gain (MWG) = Mean final weight - Mean initial weight

(c) Growth Rate $=\frac{\text { Meanfinalweight-MeanInitialWeightX } 100}{\text { DurationoftheExperiment }}$

(d) Specific Growth Rate (\%/day) $=\frac{\log _{e}\left(w t_{2}\right)-\log _{e}\left(w t_{1}\right)}{t_{2}-t}$

Where $\mathrm{Wt}_{1}=$ Initial weight gain

$\mathrm{Wt}_{2}=$ Final weight gain

$\mathrm{T}_{2}-\mathrm{T}_{1}=$ Duration (in days) considered between $\mathrm{Wt}_{2}$ and $\mathrm{Wt}_{1}$

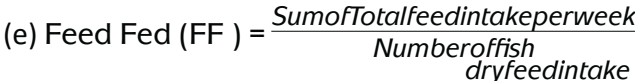

(f) Feed conversion ratio (FCR $)=\frac{\text { dryfeedintake }}{\text { wetweightgain }}$

(g) Feed efficiency ratio $($ FER $)=\frac{\text { wetweightgainx } 100}{\text { dryfeedintake }}$

(h) Protein efficiency ratio $=\frac{\text { wetweightgain }}{\text { proteinfed }}$

Where Protein fed $=\frac{\% \text { proteinindiet } \times \text { totaldietconsumed }}{100}$

(i) \% survival rate $=\frac{\text { totalnumberoffish-mortality }}{\text { totalnumberoffish }} \times 100$

Summary statistics of different variables measured across the treatment were obtained using Minitab 14 for Windows. Results were then subjected to Analysis of variance, where significant differences occurred; means were separated using Fisher's least significant difference.

\section{RESULTS AND DISCUSSION}

The aim of feed storage is to reduce the rapidity at which feed deteriorates. Hence storage never enhances feed 
quality but proper storage maintains the shelf life of feed. The different commercial fish feed stored in open conditions for the period of six months was observed to have reduced nutritional content, insect population and unpleasant smell indicating the presence of rancidity (Tables 1, 2 and 3). De Silva et al. (1995) has opined that loss of flavour and appearance of feed clumping leads to reduced palatability of stored feed. Mould growth in stored feeds has been implicated to reduce nutritional value owing to the loss of dietary lipids, amino acids (especially lysine and arginine) and vitamins by enzymatic digestion (Jones, 1987). The study observed that feed stored in open conditions had higher mould infestation compared to other storage methods (Table 3). This observation is in accordance with reports of Cockrell (1971), NRC (1981), New (1987), Effiong and Eyo (1997), and Eyo (2001). The OT stored feed had no such problem except for Vital feed ${ }^{\circ}$. Vital feed ${ }^{\circledR}$ became damp and musty but with reduced mould growth compared to the WO feeds. This could be explained by the influence of factors such as combination of the feed ingredients, chemical composition and interaction of the feed. Furthermore, the high relative humidity created within the OT stored Vital feed $^{\varpi}$ increased the dampness of the feed which in turn led to mould proliferation; the inside of other feeds held under OT conditions was noticed to be dry throughout the storage period unlike the Vital feed ${ }^{\circledR}$, highlighting the role the nature of packaging material played in feed preservation. This is in line with the observations of NRC (1981).

The percentage of crude protein (CP) content of Coppens ${ }^{\circ}$ OT condition remains fairly constant during a storage period of six months, while that of Multifeed ${ }^{\circ}$ and Vital feed ${ }^{\circ}$ reduced significantly (Table 1). This could be a result of protein ageing as postulated by Shyong (1998); however, deviation from the trend of decreased protein observed in Coppens ${ }^{\circ}$ may have been due to differences in feed ingredients and their susceptibility to protein ageing. Hossain et al. (2011) reported that changes in the chemical composition and nutritive value of feed may occur during storage. The protein content of all commercial feeds stored in the WO conditions were reduced at the end of six-month storage; hence nutrient deterioration may be said to be reduced with proper storage practices as reduction in protein levels were marginal with OT and SC storage conditions. This observation agrees with Jones (1987) and Lim et al. (2008) who reported that infestation of feed by spoilage microorganisms results in loss of dietary nutritional value owning to the loss of amino acids (especially lysine and arginine), dietary lipids and vitamins. Lipid content of Coppens was higher compared to those observed in Multifeed ${ }^{\circ}$, however, Vital feed ${ }^{\oplus}$ had the lowest lipid content both in WO and OT conditions of storage (Table 1). Ayuba and lorkohol (2013) also reported differences in lipid content of Coppens ${ }^{\circ}$, Dizengoff ${ }^{\circ}$, Durante ${ }^{\circ}$ and Adolf calyx fish feeds. The feed ingredients used in the formulations, as well as feed nutritional specification as determined by the manufacturer, may have led to this variation. The lipid content of Coppens ${ }^{\circ}$ and Vital feed was reduced at the end of storage, although Multifeed ${ }^{\circ}$ expressed less pronounced variation (Table 1). These trends could be attributed to lipid oxidation which would be dependent on feed ingredients and their susceptibility to deterioration. According to NRC (1981), feed stored for longer than 90 days (three months) at ambient temperature is subjected to the breakdown of oil and vitamins along with peroxidation of the lipid component. Rancidity resulting from lipid oxidation is the most outstanding deteriorative change in feed during storage. Feed ingredients containing lipids which are highly polyunsaturated such as fish meals are susceptible to oxidations (Pezzuto and Park, 2002; Sidhuraju and Backer, 2003). Chan (1987) reported that polyunsaturated fats can quickly autoxidize at ambient or sub-ambient temperatures.

Table 1. Proximate composition of feeds stored under different conditions

\begin{tabular}{lcccccc}
\hline \hline & Ash & Lipid & Fibre & Protein & NFE & Moisture \\
\hline Coppens $^{\circ}$ (OT) & $7.15 \pm 0.01^{\mathrm{b}}$ & $13.23 \pm 0.01^{\mathrm{a}}$ & $2.75 \pm 0.02^{\mathrm{c}}$ & $43.72 \pm 0.02^{\mathrm{e}}$ & $33.14 \pm 0.04^{\mathrm{c}}$ & $9.65 \pm 0.04^{\mathrm{c}}$ \\
Coppens $^{\circ}$ (WO) & $7.17 \pm 0.01^{\mathrm{a}}$ & $12.73 \pm 0.11^{\mathrm{b}}$ & $2.70 \pm 0.02^{\mathrm{d}}$ & $41.60 \pm 0.49^{\mathrm{f}}$ & $35.80 \pm 0.61^{\mathrm{a}}$ & $9.64 \pm 0.07^{\mathrm{d}}$ \\
Coppens $^{\circ}$ (SC) & $3.70 \pm 0.01^{\mathrm{g}}$ & $13.29 \pm 0.11^{\mathrm{a}}$ & $2.50 \pm 0.02^{\mathrm{e}}$ & $43.79 \pm 0.49^{\mathrm{e}}$ & $33.00 \pm 0.61^{\mathrm{c}}$ & $9.50 \pm 0.07^{\mathrm{e}}$ \\
Multifeed $^{\circ}$ (OT) & $5.99 \pm 0.01^{\mathrm{e}}$ & $12.71 \pm 0.02^{\mathrm{c}}$ & $2.59 \pm 0.01^{\mathrm{f}}$ & $46.17 \pm 0.20^{\mathrm{b}}$ & $32.54 \pm 0.21^{\mathrm{e}}$ & $9.47 \pm 0.04^{\mathrm{f}}$ \\
Multifeed $^{\circ}$ (WO) & $6.17 \pm 0.04^{\mathrm{d}}$ & $12.26 \pm 0.03^{\mathrm{d}}$ & $2.62 \pm 0.02^{\mathrm{e}}$ & $46.01 \pm 0.21^{\mathrm{c}}$ & $32.94 \pm 0.20^{\mathrm{d}}$ & $9.56 \pm 0.07^{\mathrm{e}}$ \\
Multifeed $^{\circ}$ (SC) & $6.08 \pm 0.04^{\mathrm{d}}$ & $12.00 \pm 0.03^{\mathrm{f}}$ & $2.50 \pm 0.02^{\mathrm{e}}$ & $47.11 \pm 0.21^{\mathrm{a}}$ & $33.94 \pm 0.20^{\mathrm{b}}$ & $9.31 \pm 0.07^{\mathrm{g}}$ \\
Vital feed $^{\circ}$ (OT) & $5.84 \pm 0.01^{\mathrm{f}}$ & $11.90 \pm 0.02^{\mathrm{e}}$ & $3.59 \pm 0.02^{\mathrm{b}}$ & $46.87 \pm 0.40^{\mathrm{a}}$ & $31.79 \pm 0.44^{\mathrm{f}}$ & $11.16 \pm 0.04^{\mathrm{b}}$ \\
Vital feed $^{\circ}$ (WO) & $6.23 \pm 0.09^{\mathrm{c}}$ & $11.44 \pm 0.09^{\mathrm{f}}$ & $3.72 \pm 0.05^{\mathrm{a}}$ & $44.03 \pm 1.25^{\mathrm{d}}$ & $34.57 \pm 1.23^{\mathrm{b}}$ & $11.50 \pm 0.10^{\mathrm{a}}$ \\
Vital feed $^{\circ}$ (SC) & $5.86 \pm 0.09^{\mathrm{f}}$ & $12.02 \pm 0.01^{\mathrm{f}}$ & $3.67 \pm 0.05^{\mathrm{a}}$ & $48.13 \pm 0.15^{\mathrm{d}}$ & $34.57 \pm 1.23^{\mathrm{b}}$ & $11.04 \pm 0.10^{\mathrm{b}}$ \\
p-value & $<0.001$ & $<0.001$ & $<0.001$ & $<0.001$ & $<0.001$ & $<0.001$ \\
S.E.M. & 0.004 & 0.005 & 0.004 & 0.005 & 0.007 & 0.003 \\
\hline \hline
\end{tabular}

Means in the same column followed by different superscripts differ significantly $(p<0.05)$

Keys: Widely open (WO), Seal Opened but tired (OT), Sealed (SC) 
The AIN (1980), however, reported that diets containing fish oil are more susceptible to autoxidation than diets containing other polyunsaturated fats. It is an established fact that different variables are involved in oil shelf-life; processing, storage conditions, light exposure, type of packing material, availability of oxygen and addition of antioxidants all affect the quality and characteristics of fats and lipids containing products (Lawson, 1995; Polvillo et al., 2004).

The magnitude of oxidative changes was monitored by periodical measurement of peroxide value (POV) and free fatty acid (Table 2). The peroxide value levels increased in

Table 2. Free Fatty Acid and peroxide value of feeds stored under different conditions

\begin{tabular}{lcc}
\hline \hline & FFA & PV \\
\hline Coppens $^{\circ}$ (OT) & $6.93 \pm 0.17^{\mathrm{f}}$ & $16.09 \pm 3.48^{\mathrm{f}}$ \\
Coppens $^{\circ}$ (WO) & $7.72 \pm 0.35^{\mathrm{d}}$ & $20.63 \pm 1.13^{\mathrm{d}}$ \\
Coppens $^{\circ}$ (SC) & $4.30 \pm 0.35^{\mathrm{i}}$ & $12.11 \pm 1.13^{\mathrm{h}}$ \\
Multifeed $^{\circ}$ (OT) & $7.49 \pm 0.18^{\mathrm{e}}$ & $18.73 \pm 0.81^{\mathrm{e}}$ \\
Multifeed $^{\circ}$ (WO) & $8.06 \pm 0.37^{\mathrm{c}}$ & $27.07 \pm 2.64^{\mathrm{b}}$ \\
Multifeed $^{\circ}$ (SC) & $5.02 \pm 0.37^{\mathrm{g}}$ & $15.02 \pm 2.64^{\mathrm{g}}$ \\
Vital feed $^{\circ}$ (OT) & $8.69 \pm 0.44^{\mathrm{b}}$ & $20.88 \pm 2.76^{\mathrm{c}}$ \\
Vital feed $^{\circ}$ (WO) & $9.12 \pm 0.74^{\mathrm{a}}$ & $28.13 \pm 3.98^{\mathrm{a}}$ \\
Vital feed $^{\circ}$ (SC) & $4.91 \pm 0.74^{\mathrm{h}}$ & $18.90 \pm 3.98^{\mathrm{e}}$ \\
p-value & $<0.001$ & $<0.001$ \\
S.E.M. & 0.0090 & 0.0132 \\
\hline \hline
\end{tabular}

Means in the same column followed by different superscripts differ significantly $(\mathrm{p}<0.05)$

Keys: Widely open (WO), Seal Opened but tired (OT), Sealed (SC)

Table 3. Total mould count and mould identified in feed stored under different conditions

\begin{tabular}{|c|c|c|}
\hline Samples & Mould count (cfu/g) & Mould Identified \\
\hline Coppens ${ }^{\circledR}$ (OT) & $4.7 \times 10^{3} \pm 0.011^{c}$ & Aspergillus flavus \\
\hline Coppens" (WO) & $5.1 \times 10^{3} \pm 0.120^{c}$ & Aspergillus flavus \\
\hline Coppens ${ }^{\circ}$ (SC) & $1.1 \times 10^{1} \pm 0.21^{c}$ & Aspergillus flavus \\
\hline Multifeed (OT) & $7.3 \times 10^{4} \pm 0.047^{b}$ & Aspergillus flavus \\
\hline Multifeed ${ }^{\circ}$ (WO) & $9.5 \times 10^{4} \pm 0.214^{b}$ & Aspergillus flavus \\
\hline Multifeed ${ }^{\circ}$ (SC) & $3.5 \times 10^{2} \pm 0.108^{b}$ & Aspergillus flavus \\
\hline Vital feed $^{\circ}(\mathrm{OT})$ & $1.2 \times 10^{5} \pm 0.412^{a}$ & $\begin{array}{l}\text { Aspergillus flavus, } \\
\text { Aspergillus niger }\end{array}$ \\
\hline Vital feed $^{\circ}$ (WO) & $2.2 \times 10^{5} \pm 0.049^{a}$ & $\begin{array}{l}\text { Aspergillus flavus, } \\
\text { Aspergillus niger }\end{array}$ \\
\hline Vital feed $^{\circ}(\mathrm{SC})$ & $0.2 \times 10^{2} \pm 0.114^{a}$ & $\begin{array}{l}\text { Aspergillus flavus, } \\
\text { Aspergillus niger }\end{array}$ \\
\hline P-Value & 0.013 & \\
\hline
\end{tabular}

Means in the same column followed by different superscript differ significantly $(\mathrm{P}<0.05)$

Keys: Widely open (WO), Seal Opened but tired (OT), Sealed (SC)
Table 4. The rainfall, temperature and relative humidity during the storage period

\begin{tabular}{lcccccc}
\hline \hline & \multicolumn{7}{c}{ MONTHS } \\
\hline Parameters & Nov & Dec & Jan & Feb & Mar & April \\
Max $\left({ }^{\circ} \mathrm{C}\right)$ & 34.0 & 34.5 & 35.9 & 38.2 & 35.2 & 31.9 \\
Min $\left({ }^{\circ} \mathrm{C}\right)$ & 19.4 & 14.5 & 18.3 & 22.7 & 23.5 & 22.8 \\
Ext Reme $\left({ }^{\circ} \mathrm{C}\right)$ & 36 & 37 & 37 & 38 & 40 & 39 \\
RH $(\%)$ & 40 & 44.21 & 47.26 & 66.38 & 58.28 & 71.53 \\
Rainfall $(\mathrm{mm})$ & 0.0 & 0.6 & 0. & 0.5 & 0.0 & 143.2 \\
\hline \hline
\end{tabular}

Source: NIMET: TAC, MKD, AIR PORT

all feeds after a period of six months, being the highest in Multifeed and the lowest in Coppen for all storage conditions. Esterbauer et al. (1986) reported that POV of fish oil diets constantly increased with time of exposure to air and under normal feeding conditions. Peroxide formation is likely to occur as susceptible polyunsaturated fatty acids are available in the oil. Increases in POV are catalyzed by free radicals, and Fritche and Johnson (1988) reported an extremely rapid autoxidation of diets with added fish oil as measured by peroxide value rapid oxidation (POV).

Aside from the fish fed with feeds held under SC conditions which had exceptional growth performance, C. gariepinus fingerlings fed Coppens ${ }^{\circ}$ and Multifeed under OT conditions were found to have better growth and survival rate compared to other diets (Table 5). This could be a result of varying crude protein levels in various diets which likely affected growth. The growth rates observed in this study compare well with the results of Amin et al. (2010) who recorded the best growth in Clarias spp fed diet containing 40\% and 58\% of crude protein (CP). It was also observed that most of the fingerlings lost movement and appetite and this resulted in starvation. This could be attributed to off-flavour and decreased palatability of the feed.

The study revealed that all the fish fed feed WO and Vital feed had higher rate of mortality. Many of the mortalities, especially of fish fed WO stored feed, had lesions on their body (Fig. 1), while others had swollen bellies (Fig. 2).

The increased mortality observed in Vital feed for all storage conditions may be an indication of poor feed acceptability as a result of feed ingredient used to produce the feed locally (Vital feed is an indigenous Nigerian locally produced fish feed). Mould infested fish feeds have been reported to negatively impact growth of vundu fish (Effiong and Alatise, 2009) and this is in line with the findings of this study. Deaths of fingerlings were likely due to feeding feeds containing toxin-producing fungi which are known to be strongly carcinogenic and mutagenic in nature (Ciceron et al., 2008). Anomalies associated with feeding mouldy feed to fish, as reported by Jantrarotai and Lovell (1990), include pale gills, impaired blood clothing, anemia, poor growth rates and loss of weight. Sergent et al. (2002) also 
Table 5. Nutrients utilization by Clarias gariepinus fingerlings fed commercial feed stored under different storage conditions

\begin{tabular}{|c|c|c|c|c|c|c|c|c|c|}
\hline Parameter & $\operatorname{MIW}(\mathrm{g})$ & MFW(g) & MWG $(g)^{*}$ & $\operatorname{MWG}(g)^{* *}$ & SGR(\%.day-1) & FCR & PER & ANPU & Survival (\%) \\
\hline Coppens $^{\circ}$ (OT) & $5.63 \pm 0.18$ & $21.38 \pm 1.60^{c}$ & $28.06 \pm 1.91^{b}$ & $15.75 \pm 1.22^{b}$ & $0.024 \pm 0.011^{c}$ & $1.36 \pm 0.07^{b}$ & $1.82 \pm 0.09^{b}$ & $0.11 \pm 0.00^{b}$ & $91.25 \pm 1.25^{b}$ \\
\hline Coppens $^{\circ}$ (WO) & $6.38 \pm 0.32$ & $7.39 \pm 0.28^{\mathrm{e}}$ & $14.11 \pm 1.55^{c}$ & $1.01 \pm 0.10^{d}$ & $0.003 \pm 0.001^{d}$ & $2.10 \pm 0.09^{a}$ & $1.24 \pm 0.05^{b c}$ & $0.08 \pm 0.01^{c}$ & $15.00 \pm 7.50^{h}$ \\
\hline Coppens $^{\circ}$ (SC) & $6.02 \pm 0.30$ & $36.18 \pm 1.00^{\mathrm{a}}$ & $27.06 \pm 0.01^{b}$ & $25.01 \pm 1.22^{\mathrm{a}}$ & $0.101 \pm 0.001^{a}$ & $1.02 \pm 0.01^{b}$ & $2.31 \pm 0.01^{\mathrm{a}}$ & $0.52 \pm 0.00^{a}$ & $98.59 \pm 0.11^{\mathrm{a}}$ \\
\hline Multifeed ${ }^{\circ}$ (OT) & $5.75 \pm 0.10$ & $29.12 \pm 0.97^{b}$ & $37.95 \pm 0.65^{\mathrm{a}}$ & $13.37 \pm 0.97^{b}$ & $0.029 \pm 0.000^{c}$ & $1.29 \pm 0.10^{b}$ & $1.82 \pm 0.14^{b}$ & $0.07 \pm 0.01^{c}$ & $61.25 \pm 6.25^{\mathrm{e}}$ \\
\hline Multifeed $^{\circ}$ (WO) & $6.00 \pm 0.30$ & $4.93 \pm 0.71^{f}$ & $7.88 \pm 1.09^{d}$ & $-1.08 \pm 0.71^{e}$ & $-0.004 \pm 0.003^{e}$ & $2.41 \pm 0.18^{\mathrm{a}}$ & $0.98 \pm 0.07^{c d}$ & $0.05 \pm 0.00^{c}$ & $31.21 \pm 3.75^{f}$ \\
\hline Multifeed $^{\circ}(\mathrm{SC})$ & $6.15 \pm 0.10$ & $32.32 \pm 0.71^{\mathrm{ab}}$ & $37.95 \pm 0.60^{\mathrm{a}}$ & $23.37 \pm 0.01^{\mathrm{a}}$ & $0.091 \pm 0.000^{\mathrm{a}}$ & $1.12 \pm 0.11^{b}$ & $2.02 \pm 0.11^{\mathrm{ab}}$ & $0.31 \pm 0.11^{\mathrm{a}}$ & $88.23 \pm 1.23^{c}$ \\
\hline Vital feed $^{\otimes}$ (OT) & $6.50 \pm 0.15$ & $7.03 \pm 0.17^{\mathrm{e}}$ & $13.92 \pm 0.52^{c}$ & $0.53 \pm 0.42^{\mathrm{d}}$ & $0.001 \pm 0.001^{\mathrm{d}}$ & $2.09 \pm 0.01^{\mathrm{a}}$ & $1.11 \pm 0.00^{c}$ & $0.06 \pm 0.00^{c}$ & $15.00 \pm 2.50^{\mathrm{h}}$ \\
\hline Vital feed $^{\circ}$ (WO) & $6.25 \pm 0.25$ & $5.79 \pm 0.61^{\text {ef }}$ & $8.79 \pm 0.08^{d}$ & $-0.46 \pm 0.36^{e}$ & $0.001 \pm 0.001^{d}$ & $2.24 \pm 0.07^{\mathrm{a}}$ & $1.11 \pm 0.04^{c}$ & $0.07 \pm 0.02^{c}$ & $26.25 \pm 1.25^{\mathrm{g}}$ \\
\hline Vital feed $^{\circ}(\mathrm{SC})$ & $6.00 \pm 0.60$ & $17.03 \pm 0.17^{d}$ & $23.92 \pm 0.92^{c}$ & $10.03 \pm 0.12^{c}$ & $0.051 \pm 0.011^{\mathrm{b}}$ & $1.50 \pm 0.02^{\mathrm{b}}$ & $0.69 \pm 0.10^{d}$ & $0.16 \pm 0.01^{b}$ & $60.00 \pm 0.19^{d}$ \\
\hline$p$-value & 0.2602 & 0.001 & 0.014 & 0.0001 & 0.0013 & 0.002 & 0.0004 & 0.0048 & 0.0008 \\
\hline
\end{tabular}

Means in the same column followed by different superscripts differ significantly $(p<0.05)$

KEY: $M I W=$ mean initial weight, $M F W=$ mean final weight, $M_{W G}^{*}=$ mean weight gain includes weight of dead fish in order to give a true FCR, MWG** = mean Weight gain excluding mortality, FCR= Feed conversion ratio, PER= Protein efficiency ratio, ANPU= Apparent net protein utilization, SGR= Specific growth rate. Keys: Widely open (WO), Seal Opened but tired (OT), Sealed (SC)
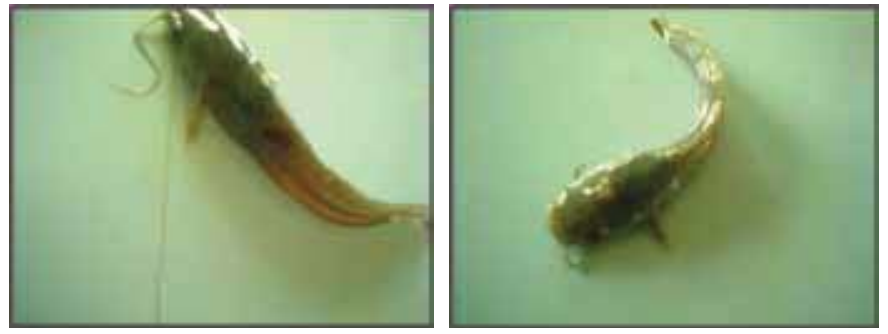

Fig 1. Observed lesions on C. gariepinus fingerlings fed mould infested feed

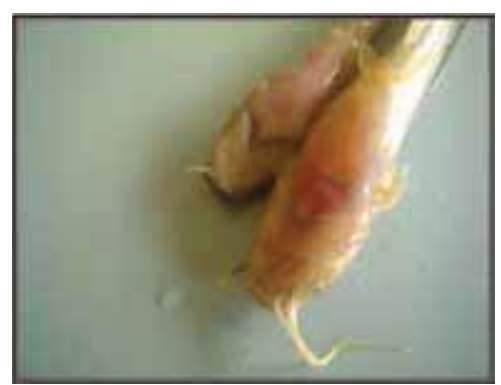

Fig 2. C. gariepinus fingerlings fed infested feed showing swollen and reddish belly

reported the pathological consequences of feeding with highly oxidized lipid include reduced growth, poor survival, liver degradation, anaemia and depletion of vitamins $E$ and C. Also work done by Arjmandi et al. (2002) reported that oxidized lipids suppress osteoblastic differentiation and may cause an increase in osteoclastic differentiation ultimately resulting in net bone loss. The difference in storage and responses of different fish species may explain different observations of these studies.

The proximate composition of $C$. gariepinus fed different commercial feeds stored under different conditions revealed considerable variation in carcass crude protein (Table 6).
The high protein content from fish fed Coppens in SC condition could be an indication that there are variations in the nutritional value of feed under SC, OT and WO conditions.

This is in line with the observation of Adewale and Omotosho (1997). The moisture content of fish in all conditions was within the acceptable range of $30-90 \%$ which is common for most fish species (FAO, 2001; Eyo, 2001). The variations in the mean proximate composition among the fish fed variously stored feeds might be attributed to the effect of holding condition and environmental factors on the feed which is then translated into observed growth (Gupta et al., 2007).

\section{CONCLUSION}

The storage of feed is crucial to ensure better keeping quality of food, the importance of packaging material for preventing or making vulnerable fish feed to deterioration was also emphasized. The study also revealed that $C$. gariepinus fingerlings are very sensitive to mouldy feed despite being considered a hardy species. More research needs to be done in this line to improve storage of feed and ensure better growth for fish.

\section{Sažetak}

\section{UČINCI UVJETA SKLADIŠTENJA NA ODLIKE KVALITETE KOMERCIJALNE RIBLJE HRANE I RASTA AFRIČKOG SOMA Clarius gariepinus}

Istraživanje je provedeno kako bi se utvrdio utjecaj uvjeta skladištenja na kakvoću hrane i posljedica učinka hranjenja 
Table 6. Proximate composition of carcass of Clarias gariepinus fingerlings fed commercial feed stored under different storage conditions

\begin{tabular}{|c|c|c|c|c|c|}
\hline & Ash & Lipid & Protein & NFE & Moisture \\
\hline Initial & $11.39 \pm 0.02^{\mathrm{a}}$ & $12.59 \pm 0.03^{b}$ & $75.31 \pm 0.03^{g}$ & $0.71 \pm 0.05^{\mathrm{e}}$ & $0.73 \pm 0.02$ \\
\hline $\begin{array}{l}\text { Coppens } \\
\text { (OT) }\end{array}$ & $7.40 \pm 0.01^{\mathrm{g}}$ & $11.58 \pm 0.02^{\mathrm{e}}$ & $79.99 \pm 0.09^{a}$ & $1.03 \pm 0.07^{\mathrm{cd}}$ & $0.64 \pm 0.02$ \\
\hline $\begin{array}{l}\text { Coppens } \\
\text { (WO) }\end{array}$ & $9.78 \pm 0.02^{d}$ & $11.19 \pm 0.02^{\mathrm{g}}$ & $77.09 \pm 0.11^{d}$ & $1.95 \pm 0.09^{a}$ & $0.67 \pm 0.01$ \\
\hline $\begin{array}{l}\text { Coppens } \\
\text { (SC) }\end{array}$ & $8.38 \pm 0.12^{d}$ & $11.11 \pm 0.02^{\mathrm{g}}$ & $80.11 \pm 0.21^{d}$ & $1.05 \pm 0.09^{a}$ & $0.64 \pm 0.01$ \\
\hline $\begin{array}{l}\text { Multifeed }^{\circ} \\
\text { (OT) }\end{array}$ & $7.57 \pm 0.01^{f}$ & $11.68 \pm 0.01^{d}$ & $79.31 \pm 0.04^{b}$ & $1.44 \pm 0.02^{b}$ & $0.69 \pm 0.01$ \\
\hline $\begin{array}{l}\text { Multifeed } \\
\text { (WO) }\end{array}$ & $11.12 \pm 0.00^{b}$ & $12.15 \pm 0.01^{\mathrm{c}}$ & $75.58 \pm 0.02^{f}$ & $1.15 \pm 0.00^{c}$ & $0.67 \pm 0.01$ \\
\hline $\begin{array}{l}\text { Multifeed }^{\circ} \\
\text { (SC) }\end{array}$ & $8.11 \pm 0.00^{b}$ & $12.05 \pm 0.01^{\mathrm{c}}$ & $78.41 \pm 0.52^{f}$ & $1.35 \pm 0.00^{c}$ & $0.67 \pm 0.01$ \\
\hline $\begin{array}{l}\text { Vital feed } \\
\text { (OT) }\end{array}$ & $9.57 \pm 0.01^{\mathrm{e}}$ & $11.42 \pm 0.03^{f}$ & $78.03 \pm 0.03^{c}$ & $0.98 \pm 0.01^{d}$ & $0.70 \pm 0.01$ \\
\hline $\begin{array}{l}\text { Vital feed } \\
\text { (WO) }\end{array}$ & $10.54 \pm 0.02^{c}$ & $12.66 \pm 0.03^{a}$ & $75.79 \pm 0.00^{\mathrm{e}}$ & $1.00 \pm 0.00^{\text {cd }}$ & $0.65 \pm 0.00$ \\
\hline $\begin{array}{l}\text { Vital feed } \\
\text { (SC) }\end{array}$ & $8.59 \pm 0.01^{c}$ & $12.00 \pm 0.03^{a}$ & $79.12 \pm 0.00^{e}$ & $0.90 \pm 0.00^{\text {cd }}$ & $0.62 \pm 0.00$ \\
\hline P-value & 0.001 & 0.001 & 0.001 & 0.001 & 0.123 \\
\hline
\end{tabular}

Means in the same column followed by different superscripts differ significantly $(\mathrm{p}<0.05)$ Keys: Widely open (WO), Seal Opened but tired (OT), Sealed (SC)

ribe s takvom hranom. Tri komercijalna hranjiva su korištena u ovom istraživanju su: Coppens ${ }^{\circledR}$, Multifeed ${ }^{\circledR}$ i Vital feed ${ }^{\circledR}$. Hrana je uskladištena: otvaranjem vreća u atmosferu (WO), otvaranjem vreća vezanih gumenim prstenom kako bi se spriječilo izlaganje atmosferi (OT) ili hermetički zatvorene vreće (SC) do početka hranjenja. Hrana je pohranjena u tim uvjetima tijekom šest mjeseci. Analiza hranjiva pokazala je značajne promjene u hrani koja se održava u WO stanju u usporedbi s drugim uvjetima skladištenja. Nutritivne promjene također su varirale s vrstom komercijalne hrane. Pojava plijesni na hrani je bila primjetno viša u WO uvjetima čuvanja u odnosu na SC uvijete. Nakon hranjenja $C$. gariepinus tijekom pedeset i šest dana, uočene su lezije na ribi koja je hranjena pljesnivom hranom, koja se skladištila pod WO uvjetima, što je dovelo do masovnih uginuća. Karakteristike rasta su bile veće kod svih riba hranjenih u SC uvjetima pohranjene hrane, kao i za one hranjene Coppens ${ }^{\circledR}$ i Multifeed ${ }^{\circledR}$ pod uvjetima COT skladištenja. Preporučljivo je da se skladištenju riblje hrane do šest mjeseci treba posvetiti znatnu brigu i pažnju.

Ključne riječi: ozljede, neposredan sastav, FFA, POV

\section{REFERENCES}

Adaga K., (2014): Nutrient profile of some commercial feeds under different storage conditions and their effect on growth performance of Clarias gariepinus. Unpublished MSc. thesis department of Fisheries and Aquaculture, University of Agriculture Makurdi Nigeria. pp 125

Adewoye, S. O., Omotosho, J. S., (1997): Nutrient composition of some freshwater Fishes in Nigeria, Stock Resources Comm., 333 pp

American Institute of Nutrition (AIN) (1980): Second report of the ad hoc committee on standards for nutritional studies. J. Nutr. 110, 1726.

American Public Health Association (APHA): (1998) Standard Methods for the Examination of Water and Waste Water. 20th Edn., Washington DC., pp. 1161.

Amin, M., Mollah, R., Ali, M. F. A., Nahiduzzaman, M. R. (2010): Effects of different food items in the growth and survival of endangered riverine catfish Rita rita (Hamilton). University Journal of Zoology. Rajshahi University, 28, 11-14. Diet formulated, Ciriunaforda within laboratory. Nigerian Journal of Pure and Applied Sciences, 17, 1253-1256.

AOAC (2002): 41.1.16 AOAC Official Method 96533 peroxide Value of oils and fats. Official methods of analysis of AOAC International, $17^{\text {th }}$ edition. Craithersberg, MD ADAC International.

Arjmandi, B. H., Juma, S., Beharka, A., Bapna, M. S., Akhter, M., Meydani, S. N., (2002): Vitamin E improves bone quality in the aged but not in young adult male mice. J. Nutr. Biochem 13, 543-549.

Ataguba, G. A., Annune P. A., Ogbe, F. G. (2010): Growth performance of two African catfishes Clarias gariepinus and Heterobranchus longifilis and their hybrids in plastic aquaria. Livestock Research for Rural Development, Vol. 22.

Ayuba V. O., Iorkohol E. K., (2012): Proximate composition of some commercial fish feeds sold in Nigeria. Journal of Fisheries and Aquatic Science 8 (1): 248252.

Bautista, M. N., Subosa P. F., Celia, R. L. (1992):.Effects Lin, C.F., A. Asghar, J.I. Gray, D.J. Buckley, A.M. Booren, of antioxidants on feed quality and growth of R.L. Crackel and C.J. Flegal, 1989. Effects of Penaeus monodon juvenile. J. Sci. Food Agri., 1: 55- oxidized dietary oil and antioxidant supplementation 60. on broiler growth and meat stability. Br. Poult. Sci.,

Berger, K. G., (1989): Practical measures to minimize rancidity in processing and storage. In: Rancidity in Foods (2nd ed.). Eds. Allen, J.C. and Hamilton, R.J. Elsevier Applied Science. London and New York.

Brown D. I. (2001): Aflatoxine: Occurrences and Health Risk in plants poisonous to Livestock. Publication of Department of Animal Science, Cornell University.

Chan, H. W. S. (1987): The mechanism of autoxidation. In: Autoxidation of Unsaturated Lipids (Chan, H.W.S.)

Ciceron, M. F. A., Del Parado, J. M., Carera E. C. (2008): A Comparative Study on the Antimicrobial Resistance of 
Escherichia coli isolates of chickens and fish grown on agricultural scientist, 91, 3, 28-33.

Cockerell, I., Francis B., Halliday, D. (1971): Changes in the nutritive value of concentrate feedstuffs during storage. Proceedings of Conference of Feed Resources and improvement of Animal feeding methods in the CENTO Region countries, Tropical products Institute, London, pp. 181-192.

Coppen, P. P., (1989): The use of antioxidants. In: Rancidity in Foods ( 2 ed.). Eds. Allen, J. C. and Hamilton, R.J. Elsevier Applied Science. London and New York.

De Silva, S. S., Anderson, T. A., (1995): Fish Nutrition in Aquaculture, Chapman and Hall. London.

Effiong, B. N., Alatise, S. P. (2009): Effect of mouldinfestated feeds on the growth and survival of Heterobrancus longifilis fingerlings. Report and opinion. (3) http./www. science pub.net

Effiong, B. N., Eyo A. A. (1997): Control of mould infestation in stored pelleted feed. NIFFR Annual Report, pp. 128-134.

Esterbnauer, H., Benedetti, A., Lang, J., Fulceri, R., Fauler, G., Comporti, M. (1986): Studies on the mechanism of formation of 4-hydroxyl-nonenal during microsomal lipids peroxidation. Biochim. Biophys. Acta 876, 154-166.

Eyo, A. A. (2001): Chemical composition and amino acid content of the commonly available feedstuffs used in fish feeds in Nigeria. Fish nutrition and fish feed Tech. (A.A. Eyoed.). pp 14- 25.

FAO (2001): How should I store my feeds. Infeeds and feeding of fish and shrimp. FAO Coporate document repository. Fisheries and aquaculture Department Rome, Italy.

Fritsche, K. L., Johnson, P. V. (1988): Rapid auxidation of fish oil in diets without added antioxidants. J. Nutr. 118, $425-426$.

Gupta, A., Akhil, S. A. S., Sehgal G. K. (2007): Growth and carcass composition of Giant freshwater pardalis (Pisces Loricariidae) in Malaysia Peninsula. Research Journal of Fisheries and Hydrobiology, 3, 2, 45-53.

Hamilton, P. B., (1989): The chemistry of rancidity in foods. Sanders, T. A., 1989. Nutritional Aspects of rancidity. In: Rancidity in Foods. (2nd ed.) Eds. Allen, J. and Rancidity in Food. (2nd Ed.) Eds. Allen, J. and Hamilton, R.J. Elsevier Applied Science. London Washington, USA. 9 October-15 December 1978. and New York. http://www. Fao.Org/Docrep/X5738e/X5738eoo.

Hossain M. S., Kabiraj, R. C., Hasan, M. A., Shaheen, M. R. U. B., Al-Azad, M. A. K. (2011): Effect of biotic and abiotic factors on quality of black gram seed. Bangladesh Res. Publications J. 5, 103-110.

Jamu, D. M., Ayinla, O. A. (2003): Potential for the development of aquaculture in Africa. NAGA, 26, 3, 6-13.

Jantrarotai, W., Lovell R.T. (1990): Subchronic toxicity of dietary aflatoxin B1 to Channel catfish. Journal of Aquatic
Animal Health 2, 248-251.

Jones, (1987): Fish Nutrition and Fish feed Technology. Ed by A.A Eyo proceeding of the first National symposium on fish Nutrition and fish feed technology Held at the Nigerian Institute for Oceanography and Marine Research (NIOMR), PP113-120.

Karapan Aglottidis (2002): Studies to optimize poly unsaturated fatty acid composition of tilapia for human consumption in S.E. Asia. Aquaculture News, 28, 6-7.

Lawson H. (1995): Food Oils and Fats: Technology, Utilization and Nutrition, 18 - 115. Chapman \& Hall, New York.

Lim, H. A., Ng, W. K., Lim, S. L., Ibrahim C. O. (2008): Contamination of palm kernel meal with Aspergillus flavus affects its nutritive value I pelleted feed for tilapia, Oreochromis mossambicus. Aquaculture Research. Vol.32 Issue 11, 895-905.

Madu C. T., Sogbesan, A. O., Ibiyo, L. M. O. (2003). Some non-conventional fish feed resources in Nigeria. In: National Workshop on Fish Feed and Feeding Practice in Aquaculture, A.A. Eyo (Ed) Published by FISON, NIFFR, FAO-NSPFS. pp. 73-83.

National Research Council, (NRC) (1981): Nutrient Requirements of Coldwater Fishes. National Academy of Sciences, Washington DC.63 pp.

New, M. B. (1987): Feeds and feeding of fish and shrimp: a manual on the preparation and presentation of compound feeds for fish and shrimp in aquaculture. FAO Report No.ADCP/REP/87/26. Rome. 275 pp.

Olufeagba, S. O. (1999): Induced triploid of Heterobranchus longifilis Val. 1840 (Fam. Clariidae) and its aquacultural potentials. Unpublished Ph.D. Thesis Dept, of Bio. Sc. I., University of Ilorin pp 166.

Pezzuto, J. M., Park E. J., (2002): Autoxidation and antioxidants, in Swarbrick J., Boylan J. C., (Eds.), Encyclopedia of Pharmaceuticals Technology, (vol. 1,2nd ed.) 97-113, Marcel Dekker Inc., New York.

Polvillo M. M., Márquez-Ruiz, G. M., Dobarganes, M. C., (2004). Oxidative stability of sunflower oils differing in unsaturation degree during long-term storage at room temperature. J. Am. Oil Chem. Soc. 81, 6, 577-583.

Ramezanzadeh, F. M., Rao, R. M. M., Windhauser, W., Cheeke, P.R. (1999): Applied Animal Nutrition. Feeds And Prinyawiwatkul, R. Tulley and W.E. Marshall, 1999.Feeding (2nd ed.). Prentice Hall, Upper Saddle River. Freshwater Fishes in Nigeria, Stock Resources Comm., 333Pp.

Rossu, J. R., Yanong, R. P. E., (2006): Moulds in fish feeds and Aflatoxicosis. Fact sheet FA -95 Service.Institute of Food Agric Science University of Florida.

Ruiz, J. A., Perez-Vendreli A. M., Esteve-Garcia, E. (2000). Effect of dietary iron and copper on performance and oxidative stability in broiler leg meat. Br. Poult. Sci., 41, 163-167. 
Sargent, J. R., Tocher, D. R., Bell, J. G., (2002): The lipids, In: Halver, J.E., Sotolu,

Shyong, W. J., Haung C H., Chen, H. C. (1998): Effects of dietary protein concentration on growth and muscle composition of juvenile. Aquaculture, 167. 35-42.

Siddhuraju, P., Becker K. (2003): Antioxidant properties of various solvent extracts of total phenolic constituents from three different agroclimatic origins of drumstick tree (M. Oleifera Lam.). J. Agric. Food Chem., 51, 21442155.
Solomon, S. G., Okomoda V. T., Ochai L., (2013): Growth responses of pure bred Heterobranchusbidorsalis, Clarias gariepinus and their intergeneric crosses fed Commecial diet, Banat's Journal of Biotechnology 8 , 6, 71-76

Van den Berghe, C. H., Ahouangninou, P. O., Deka, E. K. (1990). The effect of antioxidant and mold inhibitor on feed quality and the performance of broilers under tropical conditions. Trop. Sci., 30, 5-13. 